\title{
Correction to: Probiotics' efficacy in paediatric diseases: which is the evidence? A critical review on behalf of the Italian Society of Pediatrics
}

\author{
Massimo Martinelli ${ }^{1}$, Giuseppe Banderali ${ }^{2}$, Marisa Bobbio ${ }^{3}$, Elisa Civardi ${ }^{4}$, Alberto Chiara ${ }^{4}$, Sofia D’Elios ${ }^{5}$, \\ Andrea Lo Vecchio ${ }^{1}$, Mattia Olivero ${ }^{3}$, Diego Peroni ${ }^{5}$, Claudio Romano ${ }^{6}$, Mauro Stronati ${ }^{4}$, Renato Turra ${ }^{3}$, Irene Viola ${ }^{6}$, \\ Annamaria Staiano $^{1 *}$ and Alberto Villani ${ }^{7}$
}

\section{Correction to: Ital J Pediatr 46, 104 (2020) https://doi.org/10.1186/s13052-020-00862-z}

One of the studies included in this review [1] assessed a probiotic formulation known as VSL\# 3. The probiotic formulation that was assessed in this study is now known by the generic name 'De Simone Formulation'. The current product known as VSL\# 3 is not the same formulation as the original product invented by Professor De Simone. The authors would like to apologise for any inconvenience caused.

\section{Author details}

'Department of Translational Medical Science, Section of Pediatrics, University of Naples "Federico II", Via S. Pansini, 5, 80131 Naples, Italy. ${ }^{2}$ ClinicalDepartment of Pediatrics and Neonatology, San Paolo Hospital, ASST Santi Paolo e Carlo, University of Milan, Milan, Italy. ${ }^{3}$ ASL TO4 Piemonte, Turin, Italy. ${ }^{4}$ Neonatal Intensive Care Unit, Fondazione IRCCS Policlinico San Matteo Pavia, Pavia, Italy. ${ }^{5}$ Department of Clinical and Experimental Medicine, Section of Pediatrics, University of Pisa, Pisa, Italy. ${ }^{6}$ Pediatric Gastroenterology and Cystic Fibrosis Unit, University of Messina, Messina, Italy. ${ }^{7}$ Pediatric and Infectious Disease Unit, Bambino Gesù Children's Hospital, IRCCS, Rome, Italy.
Received: 12 August 2020 Accepted: 12 August 2020

Published online: 17 August 2020

\section{Reference}

1. Martinelli M, Banderali G, Bobbio M, et al. Probiotics' efficacy in paediatric diseases: which is the evidence? A critical review on behalf of the Italian Society of Pediatrics. Ital J Pediatr. 2020;46:104 https://doi.org/10.1186/ s13052-020-00862-z.

The original article can be found online at https://doi.org/10.1186/s13052020-00862-z

*Correspondence: staiano@unina.it

'Department of Translational Medical Science, Section of Pediatrics, University of Naples "Federico II", Via S. Pansini, 5, 80131 Naples, Italy

Full list of author information is available at the end of the article

C C The Author(s). 2020 Open Access This article is licensed under a Creative Commons Attribution 4.0 International License, which permits use, sharing, adaptation, distribution and reproduction in any medium or format, as long as you give appropriate credit to the original author(s) and the source, provide a link to the Creative Commons licence, and indicate if changes were made. The images or other third party material in this article are included in the article's Creative Commons. licence, unless indicated otherwise in a credit line to the material. If material is not included in the article's Creative Commons licence and your intended use is not permitted by statutory regulation or exceeds the permitted use, you will need to obtain permission directly from the copyright holder. To view a copy of this licence, visit http://creativecommons.org/licenses/by/4.0/ The Creative Commons Public Domain Dedication waiver (http://creativecommons.org/publicdomain/zero/1.0/) applies to the data made available in this article, unless otherwise stated in a credit line to the data. 